В. В. Бойко, В. О. Прасол, Д. В. Оклей, І. А. Тарабан

ДУ «Інститут загальної та невідкладної хірургії імені В. Т. Зайщева НАМНУ», м. Харків
DOI:https://doi.org/10.37699/2308-7005.3-4.2019.14

\section{КЛІНІЧНА ЕФЕКТИВНІСТЬ ТА БЕЗПЕКА АМБУЛАТОРНОГО ЛІКУВАННЯ ХВОРИХ IЗ ТРОМБОЗОМ ГЛИБОКИХ ВЕН НИЖНІХ КІНЦІВОК}

Резюме. У роботі вивчені результати стаціонарного та амбулаторного хірургічного лікування хворих з тромбозом глибоких вен (ТГВ) нижніх кінцівок. Проведено порівняльний аналіз клінічної ефективності й безпеки амбулаторного та стаціонарного режимів антикоагулянтної терапії ТГВ. На підставі цього, виділені показання для амбулаторного хірургічного лікування хворих з ТГВ.

Ключові слова: тромбоз глибоких вен (ТГВ), антикоагулянтна терапія, стаціонарне та амбулаторне лікування.

\section{Вступ}

Актуальність лікування хворих 3 гострими тромбозами вен нижніх кінцівок залишається незаперечною і на сьогоднішній день через високу частоту розповсюдженості цього захворювання і ускладнень, що виникають і загрожують життю: тромбоемболії легеневої артерії (ТЕЛА), важкі форми хронічної венозної недостатності (XBH) i ін. $[1,2]$.

За даними епідеміологічних досліджень, частота ТГВ нижніх кінцівок в загальній популяції щорічно складає від 56 до 160 випадків на 100000 населення і досягає 500 випадків на 100000 чоловік у старших вікових групах, маючи стійку тенденцію до збільшення. При цьому частота ТЕЛА - найбільш небезпечного ускладнення ТГВ з летальним наслідком за даними аутопсії становить 50 випадків на 100000 чоловік в рік $[3,4]$. ТГВ нижніх кінцівок і ТЕЛА зараз розглядаються у вигляді двох аспектів одного і того ж патологічного процесу - венозного тромбоемболізму (ВТЕ), який і провокує виникнення високої смертності [5].

Ще одна проблема, пов'язана з ТГВ, - в якому медичному закладі необхідно лікувати пацієнта з ТГВ, адже в Україні покази для амбулаторного лікування визначені тільки для пацієнтів 3 тромбозом поверхневих вен, а пацієнти, які страждають ТГВ традиційно лікуються в стаціонарі [6].

У той же час $є$ підтвердження про можливість лікування хворих ТГВ емболобезпечних форм амбулатурно $[7,8,9]$. Саме тому виникає необхідність встановлення регламенту відбору пацієнтів 3 ТГВ, їх обстеження, схем лікування та визначення їх ефективності та безпеки поза стаціонаром.

\title{
Мета досліджень
}

Вивчити результати стаціонарного і амбулаторного хірургічного лікування хворих з тромбозом глибоких вен нижніх кінцівок; провести їх порівняльний аналіз.

\section{Матеріали та методи досліджень.}

У дослідження включили 109 хворих (62 жінки і 47 чоловіків) з давністю захворювання до двох тижнів. Вік пацієнтів варіював від 29 до 72 років (середній вік - 63 роки).

Залежно від місця проведення антикоагулянтної терапії (амбулаторно або в стаціонарі) всі досліджувані були розділені на дві групи (табл. 1).

У I групу (амбулаторну) було включено 45 пацієнтів 3 тромботичним ураженням глибоких вен тібіального, тібіально-підколінного і стегнового сегментів, які за різних причин відмовилися від госпіталізації в стаціонар. Усі хворі цієї групи були соціально адаптовані, у них була відсутня важка супутня патологія, не було клінічних ознак легеневої емболії. У II гру-

Таблиия 1

Розподіл хворих за віком, статтю, протяжністю тромботичного ураження, характером проксимальної частини тромбу в групах

\begin{tabular}{|c|c|c|c|}
\hline \multicolumn{2}{|l|}{ Показники } & $\begin{array}{c}\text { Група I } \\
\text { (амбулаторна) } n=45\end{array}$ & $\begin{array}{c}\text { Група II } \\
\text { (стаціонарна) } \mathrm{n}=64\end{array}$ \\
\hline \multicolumn{2}{|l|}{ Середній вік } & $62 \pm 7,6$ & $64 \pm 6,5$ \\
\hline \multicolumn{2}{|l|}{ Чоловіки/жінки } & $19 / 26$ & $28 / 36$ \\
\hline \multirow{3}{*}{ Локалізація тромбозу (сегмент) } & Тібіальний & $31(68,9 \%)$ & $42(65,6 \%)$ \\
\hline & Тібіально-підколінний & $8(17,8 \%)$ & $12(18,8 \%)$ \\
\hline & Стегневий & $6(13,3 \%)$ & $10(15,6 \%)$ \\
\hline \multirow{2}{*}{ Сторона ураження } & Зліва & $24(53,3 \%)$ & $35(54,7 \%)$ \\
\hline & Зправа & $21(46,7 \%)$ & $29(45,3 \%)$ \\
\hline \multirow{2}{*}{ Характер проксимальної частини тромбу } & Оклюзивний & $37(82,2 \%)$ & $47(73,4 \%)$ \\
\hline & Неоклюзивний & $8(17,8 \%)$ & $17(26,6 \%)$ \\
\hline
\end{tabular}


пу (стаціонарну) включили 64 хворих 3 подібним характером тромботичного ураження, які відповідно до традиційної тактики ведення були госпіталізовані до стаціонару.

Розподіл хворих за віком, статтю, протяжністю тромботичного ураження, характером проксимальної частини тромбу в групах було порівнянним. Частка пацієнтів 3 неокклюзивним тромбозом, а також ураженням стегнового сегмента в II (стаціонарній) групі була більше.

Усім пацієнтам, що проходили лікування як амбулаторно, так і в стаціонарі, виконували мультиспіральну КТ-ангіопульмонографію як метод скринінгової діагностики легеневої емболії.

\section{Результати досліджень та їх обговорення.}

В обох групах антикоагулянтну терапію проводили низькомолекулярним гепарином (НМГ). Використовували еноксапарин натрію (Клексан®). Пацієнтів I групи навчали методиці введення НМГ. Його дозу розраховували відповідно до маси тіла $-1,5$ мг на 1 кг маси тіла 3 кратністю введення один раз на добу кожні 24 години під шкіру передньої черевної стінки. Також призначали компресійну терапію, навчаючи, при необхідності, техніці накладення бандажа. У II групі введення еноксапарину натрію (в дозі 1,0 мг на 1 кг маси тіла 3 кратністю введення два рази на добу кожні 12 годин) і накладення компресійних бандажів здійснював медичний персонал стаціонару.

Для профілактики рецидиву венозного тромбозу використовували варфарин, який призначали в дозі 5-7,5 мг один раз на день на 1-3 добу введення НМГ. Контроль терапії здійснювали шляхом визначення міжнародного нормалізованого відношення (МНВ). Дослідження виконували до початку лікування, а з третьої доби від початку прийому непрямого антикоагулянту МНВ визначали щодня або через добу. Дозу варфарина вважали підібраною, якщо значення МНВ в двох послідовних дослідженнях відповідали терапевтичним значенням $(2,0-3,0)$. В подальшому лабораторний контроль проводили через 2 тижні з обов'язковою корекцією дози в разі потреби. Тривалість прийому Варфарина становила не менше 6 місяців.

Хворим рекомендували дотримуватися дієти 3 низьким вмістом вітаміну К, пояснювали необхідність регулярного лабораторного контролю, попереджали про можливі ускладнення, пов'язаних 3 прийомом непрямого антикоагулянту в разі травми, хірургічних втручань, прийому інших препаратів і алкоголю. Всі пацієнти використовували протягом перших 2-3 тижнів еластичне бинтування нижніх кінцівок, а потім - носіння лікувального компресійного трикотажу 3 класу.

Результати лікування оцінювали за динамікою показників системи гемо- стазу, частотою і тяжкістю ускладнень венозного тромбозу та антикоа- гулянтної терапії, станом венозного русла і якості життя хворих.

Так, достовірних відмінностей значень АЧТЧ і ТЧ у пацієнтів першої та другої групи в процесі лікування НМГ виявлено не було. Результати представлені в таблиці 2.

Таблиия 2

Динаміка гемостазіологічних показників в групах

\begin{tabular}{|c|c|c|c|c|}
\hline \multirow{3}{*}{$\begin{array}{l}\text { Термін ліку- } \\
\text { вання, діб }\end{array}$} & \multicolumn{2}{|c|}{ Група I (амбулаторна) } & \multicolumn{2}{|c|}{ Група II (стаціонарна) } \\
\hline & \multicolumn{4}{|c|}{ Показники } \\
\hline & АЧТЧ (c) & T4 (c) & АЧТЧ (c) & T4 (c) \\
\hline $\begin{array}{c}\text { При } \\
\text { зверненні }\end{array}$ & $28,1 \pm 1,3$ & $17,2 \pm 0,3$ & $32,1 \pm 2,1$ & $19,2 \pm 0,7$ \\
\hline 1 & $29,6 \pm 1,5$ & $17,4 \pm 0,3$ & $35,2 \pm 1,6$ & $19,7 \pm 0,9$ \\
\hline 2 & $31,5 \pm 2,1$ & $18,3 \pm 1,1^{*}$ & $31,2 \pm 1,9$ & $17,2 \pm 0,4$ \\
\hline 3 & $30,3 . \pm 1,6$ & $17,5 \pm 0,3$ & $33,1 \pm 1,3$ & $18,7 \pm 0,4$ \\
\hline 4 & $35,4 \pm 2,1^{*}$ & $20,9 \pm 0,9$ & $37,2 \pm 1,8$ & $23,2 \pm 0,3^{*}$ \\
\hline 5 & $39,2 \pm 1,9$ & $21,2 \pm 0,2$ & $41,2 \pm 2,1^{*}$ & $22,3 \pm 0,4$ \\
\hline 6 & $37,6 \pm 1,2$ & $20,3 \pm 0,6$ & $42,2 \pm 1,9$ & $21,3 \pm 0,6$ \\
\hline 7 & $40,1 \pm 2,0$ & $19,7 \pm 0,4$ & $40,4 \pm 1,6$ & $20,1 \pm 0,5$ \\
\hline 8 & $42,6 \pm 1,9$ & $21,8 \pm 0,5$. & $43,1 \pm 1,8$ & $21,4 \pm 0,7$ \\
\hline
\end{tabular}

Примітка. 3 позначкою * - p $<0,05$; без позначки * $\mathrm{p}<0,01$

Як видно з таблиці, перші чотири доби показники АЧТЧ і ТЧ лишалися в межах нормальних величин. Незначне їх збільшення відзначено $з 5$ доби, що обумовлено, мабуть, впливом на систему гемостазу непрямих антикоагулянтів. Корекцію дози НМГ при цьому не проводили. Як видно 3 представлених даних застосування еноксапарину натрію 3 першої по четверту добу лікування не приводило до статистично значимого відхилення показників АЧТЧ і ТЧ від норми ( $<<0,05)$.

Починаючи 3 п'ятої доби у пацієнтів обох груп розвивалася стійка виражена гіпокоагуляція, що пов'язаназ початком дії непрямих антикоагулянтів, інактивуючих К-залежні фактори згортання крові.

Оскільки стандартні коагуляційні тести при застосуванні НМГ не відображали реальні зміни системи гемостазу, що відбувалися, ми визначали активність X фактора згортання крові. На тлі проведеної терапії виявлено закономірне зниження активності X фактора (табл. 3).

Табличя 3

Динаміка активності $\mathrm{X}$ фактора в групах

\begin{tabular}{|c|c|c|c|}
\hline $\begin{array}{c}\text { Термін } \\
\text { лікування, } \\
\text { діб }\end{array}$ & $\begin{array}{c}\text { Група I } \\
\text { (амбулаторна) } \\
\text { (\%) }\end{array}$ & $\begin{array}{c}\text { Група II } \\
\text { (стаціонарна) } \\
\text { (\%) }\end{array}$ & $\begin{array}{c}\text { Середнє } \\
\text { значення (\%) }\end{array}$ \\
\hline $\begin{array}{c}\text { При } \\
\text { зверненні }\end{array}$ & $98,4 \pm 2,1$ & $104,6 \pm 2,4$ & $101,9 \pm 3,6^{*}$ \\
\hline 1 & $99,4 \pm 2,1$ & $102,2 \pm 1,9$ & $100,3 \pm 1,8$ \\
\hline 2 & $91,6 \pm 2,8^{*}$ & $93,4 \pm 2,1$ & $92,2 \pm 1,7$ \\
\hline 3 & $82,2 \pm 2,1$ & $87,0 \pm 1,6$ & $84,6 \pm 5,7^{*}$ \\
\hline 4 & $69,2 \pm 1,2$ & $76,3 \pm 2,1$ & $72,9 \pm 2,0$ \\
\hline 5 & $60,7 \pm 1,8$ & $74,9 \pm 2,1$ & $67,8 \pm 6,2^{*}$ \\
\hline
\end{tabular}

Примітка. Із позначкою * - p <0,05; без позначки * $-\mathrm{p}<0,01$

Значне падіння активністі X фактора на п’яту добу пов'язано з прийомом антагоніста вітаміну 
К, оскільки корекції дози прямих антикоагулянтів ні в одній групі не проводилося. 3 огляду на те, що Х фактор є вітамін К-залежний, після п’ятої доби терапії його не визначали.

Раннє призначення антагоністів вітаміну $\mathrm{K}$ не тільки зменшує тривалість застосування прямих антикоагулянтів, але і дозволяє швидше перервати каскад коагуляції. Необхідні значення МНВ були досягнуті на 4-7 добу від початку застосування антагоністів вітаміну К. Динаміка змін МНВ представлена в таблиці 4.

Таблиия 4

Динаміка змін МНВ в групах

\begin{tabular}{|c|c|c|}
\hline $\begin{array}{c}\text { Термін } \\
\text { лікування, діб }\end{array}$ & $\begin{array}{c}\text { Група I } \\
\text { (амбулаторна) }\end{array}$ & $\begin{array}{c}\text { Група II } \\
\text { (стаціонарна) }\end{array}$ \\
\hline При зверненні & $1,1 \pm 0,3$ & $0,9 \pm 0,1$ \\
\hline 1 & $1,24 \pm 0,3$ & $1,2 \pm 0,3$ \\
\hline 2 & $1,45 \pm 0,6^{*}$ & $1,54 \pm 0,1$ \\
\hline 3 & $1,76 \pm 0,5$ & $1,87 \pm 0,3$ \\
\hline 4 & $1,98 \pm 0,7$ & $2,01 \pm 0,4$ \\
\hline 5 & $2,12 \pm 0,3$ & $2,23 \pm 0,3^{*}$ \\
\hline 6 & $2,43 \pm 0,3^{*}$ & $2,64 \pm 0,4$ \\
\hline 7 & $2,68 \pm 0,4$ & $2,75 \pm 0,3$ \\
\hline
\end{tabular}

Примітка. Із позначкою * - $\mathrm{p}<0,05$; без позначки * $\mathrm{p}<0,01$

Середня тривалість застосування еноксапарину натрію склала близько 6 діб і була практично однаковою в обох групах.

На амбулаторному етапі лікування МНВ визначали 3 частотою не рідше ніж один раз на п'ять днів, при стабілізації показників - не рідше 1 разу на 2 тижня. Найменші значення МНВ були зафіксовані на третій місяць лікування: корекція дози щомісячно проводилася у кожного другоготретього пацієнта.

Амбулаторний та стаціонарний режими антикоагулянтної терапії ми оцінювали за кінцевим клінічним результатом. В якості критеріїв використовували такі показники: частоту розвитку легеневої емболії, наростання протяжності тромботичного ураження вен. Безпеку терапії оцінювали за частотою і тяжкістю геморагічних ускладнень.

3 метою виявлення ТЕЛА, в тому числі і без клінічних проявів, ми використовували мультиспіральну КТ-ангіопульмонографію. Контрольну КТ-ангіопульмонографію проводили через два тижні терапії. Результати обстеження представлені в таблиці 5.

Таблиия 5

Частота виявлення тромбоемболії легеневих артерій за даними КТ-ангіопульмонографіi

\begin{tabular}{|l|c|c|}
\hline \multirow{2}{*}{ Група хворих } & \multicolumn{2}{|c|}{ Число випадків ТЕЛА, $\mathbf{n}(\%)$} \\
\cline { 2 - 3 } & До лікування & На тлі терапії \\
\hline $\begin{array}{l}\text { Група I (амбулаторна) } \\
(\mathrm{n}=45)\end{array}$ & $5(11,1 \%)$ & 0 \\
\hline $\begin{array}{l}\text { Група II (стаціонарна) } \\
(\mathrm{n}=64)\end{array}$ & $13(20,3 \%)$ & 0 \\
\hline Всього (n=109) & $18(16,5 \%)$ & 0 \\
\hline
\end{tabular}

Об'єктивні інструментальні ознаки легеневої емболії до початку антикоагулянтної терапії були виявлені в 18 (16,5\%) випадках. Початкова відмінність в частоті даного ускладнення пояснюється умовами формування амбулаторної групи хворих, де виявляли безсимптомне ураження дрібних гілок легеневого артеріального русла. У жодного пацієнта не виявлено емболізації легеневого артеріального русла в ході проведеної антикоагулянтної терапії.

Нами було відзначено, що у пацієнтів з верифікованою ТЕЛА на тлі антикоагулянтної терапії йшло досить швидке відновлення легеневого кровотоку. При контрольній ангіопульмонографіі відзначали нормалізацію перфузії легень, відновлення легеневого кровотоку в тих зонах, де раніше не спостерігалося кровопостачання. Це було відзначено у 8 (44,4 \%) пацієнтів 3 легеневою емболією на 10-ту добу терапії.

Для оцінки ефективності та безпеки терапії ми виконували контрольне ультразвукове ангіосканування вен нижніх кінцівок на п'яту добу лікування. У більшості випадків спостереження, змін в протяжності тромботичного процесу ми не виявили. Разом 3 тим, в I (амбулаторній) групі у хворих частіше відзначали зменшення протяжності тромботичного ураження венозного русла, що пояснюється, мабуть, їх більшою руховою активністю $(\mathrm{p}>0,05)$. У той же час серед пацієнтів, які перебували на стаціонарному лікуванні, частіше відбувалося наростання рівня тромбозу ( $\mathrm{p}>0,05)$. Результати проведеного обстеження представлені в таблиці 6.

Таблиия 6

Зміна довжини тромботичного ураження вен в процесі лікування на 10-ту добу

\begin{tabular}{|l|c|c|c|}
\hline \multirow{2}{*}{ Група хворих } & \multicolumn{3}{|c|}{ Протяжність тромбозу } \\
\cline { 2 - 4 } & $\begin{array}{c}\text { 3менши- } \\
\text { лася, } \\
\text { n (\%) }\end{array}$ & $\begin{array}{c}\text { Без } \\
\text { динаміки, } \\
\mathbf{n}(\%)\end{array}$ & $\begin{array}{c}\text { 3біль- } \\
\text { шилася, } \\
\mathbf{n}(\%)\end{array}$ \\
\hline $\begin{array}{l}\text { Група I (амбулаторна) } \\
(\mathrm{n}=45)\end{array}$ & $16(35,6 \%)$ & $28(62,2 \%)$ & $1(2,2 \%)$ \\
\hline $\begin{array}{l}\text { Група II (стаціонарна) } \\
(\mathrm{n}=64)\end{array}$ & $17(26,6 \%)$ & $44(68,8 \%)$ & $3(4,7 \%)$ \\
\hline Всього ( $\mathrm{n}=109)$ & $33(30,3 \%)$ & $72(66,1 \%)$ & $4(3,7 \%)$ \\
\hline
\end{tabular}

Необхідно підкреслити, що компресія в поєднанні 3 активним руховим режимом служить важливою складовою успішного лікування ТГВ, поряд 3 антикоагулянтною терапією. Доведено, що активна робота м'язово-венозної помпи в умовах зовнішньої компресії за рахунок прискорення кровотоку по глибоких венах i збільшення синтезу активатора тканинного плазміногену не тільки перешкоджає подальшому поширенню тромбоза і зменшує ймовірність його рецидиву, але й сприяє швидшій реканалізації. Крім того, доведено, що при активному веденні пацієнтів 3 ТГВ знижується ризик посттромботичного синдрому (ПТС) [10]. Все це пояснює як у амбулатор- 
них хворих раніше з'явилися ознаки початкової реканалізації.

Так, початкова ступінь реканалізації венозного русла на 10 добу терапії була відзначена у 23 (21,1\%) пацієнтів обох груп (табл. 7), при цьому частка таких пацієнтів в амбулаторній групі була більше ( $>>0,05)$. В подальшому, після зменшення набряку і стихання болю в кінцівки, пацієнти переходили на використання лікувального компресійного трикотажу 3 класу компресії до третього місяця терапії, який у пацієнтів обох груп вже проходив в амбулаторних умовах, ця різниця нівелювалася.

Таблиия 7

Розподіл пацієнтів з початковим ступенем реканалізації венозного русла

\begin{tabular}{|c|c|}
\hline Група хворих & Кількість хворих $\mathbf{n}(\%)$ \\
\hline Група I (амбулаторна) $(\mathrm{n}=45)$ & $12(26,7 \%)$ \\
\hline Група II (стаціонарна) (n=64) & $11(17,2 \%)$ \\
\hline Всього $(\mathrm{n}=109)$ & $23(21,1 \%)$ \\
\hline
\end{tabular}

У жодного з пацієнтів не було відзначено на тлі антикоагулянтної терапії формування емболонебезпечних тромбів. Розвитку алергічних реакції на препарати, що використовувалися в лікуванні не спостерігали. Летальних випадків не було.

До недоліків амбулаторного лікування ТГВ за допомогою НМГ та АВК можна віднести необхідність на початковому етапі підшкірних ін'єкцій один або два рази на добу в залежності від конкретного препарату НМГ, а також суворий контроль MHO в подальшому, для чого необхідні регулярні забори крові. Крім того, прийом АВК пов'язаний 3 великою кількістю взаємодій з іншими лікарськи- ми препаратами, а також строгими дієтичними обмеженнями. Ось чому перспективним є застосування нових оральних антикоагулянтів (НОАК) із селективним механізмом дії. Після численних рандомізованих клінічних досліджень НОАК стали використовувати для лікування, в тому числі і амбулаторного, пацієнтів з гострим ТГВ $[11,12]$.

\section{Висновки}

Таким чином, амбулаторне лікування тромбозу глибоких вен нижніх кінцівок ефективно i безпечно у соціально адаптованих пацієнтів працездатного віку 3 дистальним або сегментарним емболобезпечним тромботичним ураженням, у відсутності виражених клінічних ознак легеневої емболії, важкої супутньої патології та при наявності умов для регулярного лікарського і ультразвукового контролю за станом венозного русла. Крім цього, лікування в амбулаторних умовах сприяє більшій фізичній активності хворих, стабілізації тромботичного процесу і покращує якість життя пацієнтів.

\section{Перспективи подальших досліджень}

Сьогоднішній рівень оснащення лікувально-профілактичних установ мегаполісів i peгіональних центрів дозволяє успішно проводити лікування такої складної патології як тромбоз глибоких вен нижніх кінцівок в амбулаторних умовах, для чого найчастіше потрібна тільки зміна менталітету керівників органів охорони здоров'я, а також відповідна професійна підготовка лікарів поліклінічного та амбулаторної ланки.

\section{ЛIТЕРАТУРА}

1. Українські міждисциплінарні клінічні рекомендації по профілактиці, діагностиці та лікуванню венозних тромбоемболічних ускладнень / В. Н. Бойко, П. І. Болдіжар, I. К. Венгер, С. І. Герасименко та ін. // Клінічна флебологія. - 2017. — №10(1). С. 42-104.

2. Lack of association between venous hemodynamics, venous morphology and the postthrombotic syndrome after upper extremity deep venous thrombosis / Czihal M, Paul S, Rademacher A, Bernau C, Hoffmann U. // Phlebology. 2015. — № 30(2). С. 105-112.

3. Источники тромбоэмболии легочных артерий по данным патологоанатомического и клинического исследований / А. В. Сажин, И. С. Лебедев, С. Г. Гаврилов, Т. В. Нечай и др. // Флебология. - 2019. — № 13(3). - С. 202-210.

4. Никулина Н. Н. Эпидемиология тромбоэмболии легочной артерии в современном мире: анализ заболеваемости, смертности и проблем их изучения / Н. Н. Никулина, Ю. В. Тереховская // Российский кардиологический журнал. - 2019. - № 6. С. 103-104.

5. К вопросу о лечении тромбозов глубоких вен системы нижней полой вены, осложненных тромбоэмболией легочной артерии - возможности и результаты / Л. М. Чернуха, О. М. Скупой, О. И. Митюк, Я. В. Хребтий // Новости хирургии. - 2015. - № 3. - С 309-313.
6. Мішалов В. Г. Особливості вибору тактики лікування хворих з гострими венозними тромбозами в ранні строки захворювання / В.Г. Мішалов, Д. С. Миргородський, Л. Ю. Маркулан // Клінічна флебологія. - 2012. №5(1). - C. 112-113.

7. Utne K. K. Health-related quality of life after deep vein thrombosis / Utne KK, Tavoly M, Wik HS. // Springerplus. - 2016. - Aug 8. - 5(1). - P. 1278.

8. Амбулаторное лечение тромбоза глубоких вен нижних конечностей. Новые возможности и перспективы. Стационарозамещающие технологии / Богачев ВЮ, Болдин БВ, Родионов СВ, Дженина ОВ. // Амбулаторная хирургия. - 2017. - № 1-2. - С. 65-66.

9. Особливості амбулаторного лікування хворих з тромбозом глибоких вен нижніх кінцівок / В. В. Бойко, В. О. Прасол, Д. В. Оклей, І. А. Тарабан, К. В. Мішеніна // Харківська хірургічна школа. - 2018. № 5-6(92-93). C. 128-130.

10. Roberts L. N. Postthrombotic syndrome is an independent determinant of health-related quality of life following both first proximal and distal deep vein thrombosis / Roberts L. N., Patel R.K, Donaldson N. // Haematologica. - 2014 . № 99(3). - P. 41-43. 
11. Schulman S. Treatment of acute venous thromboembolism with dabigatran or warfarin and pooled analysis / Schulman S, Kakkar AK, Goldhaber SZ.// Circulation. — 2014. № 129. - P. 764-772.
12. Kline J. A.Outpatient treatment of low-risk venous thromboembolism with mono-therapy oral anticoagulation: patient quality of life outcomes and clinician acceptance / Kline JA, Kahler ZP, Beam DM. // Patient Preference and Adherence. — 2016. — № 10. — P.561-9.

\section{КЛИНИЧЕСКАЯ}

ЭФФЕКТИВНОСТЬ

И БЕЗОПАСНОСТЬ

АМБУЛАТОРНОГО

ЛЕЧЕНИЯ БОЛЬНЫХ С ТРОМБОЗОМ ГЛУБОКИХ ВЕН НИЖНИХ КОНЕЧНОСТЕЙ

\section{В. В. Бойко, В. А. Прасол,} Д. В. Оклей, И. А. Тарабан

CLINICAL EFFICACY AND SAFETY OF OUTPATIENT TREATMENT OF PATIENTS WITH DEEP VEIN THROMBOSIS OF THE LOWER EXTREMITIES.

\section{V. Boyko, V. A. Prasol,} D. V. Oklei, I. A. Taraban
Резюме. В работе изучены результаты стационарного и амбулаторного хирургического лечения больных с тромбозом глубоких вен (ТГВ) нижних конечностей. Проведен сравнительный анализ клинической эффективности и безопасности амбулаторного и стационарного режимов антикоагулянтной терапии ТГВ. На основании этого, выделены показания для амбулаторного хирургического лечения больных с ТГВ.

Ключевые слова: тромбоз глубоких вен (ТГВ), антикоагулянтная терапия, стационарное и амбулаторное лечение.

Summary. We studied the results of stationary and ambulatory surgical treatment of patients with deep vein thrombosis (DVT) of the lower extremities. A comparative analysis of clinical efficacy and safety of ambulatory and stationary modes of anticoagulant therapy of DVT. Based on this, marked indications for ambulatory surgical treatment of patients with DVT.

Key words: deep venous thrombosis (DVT), anticoagulant therapy, stationary and ambulatory treatment. 